\title{
Sanctions and their role in preventing the appropriation of the creditor's property rights in bankruptcy proceedings-the case of Poland ${ }^{1}$
}

\author{
Sylwia Morawska ${ }^{2}$, Błażej Prusak ${ }^{3}$, Przemysław Banasik ${ }^{3}$, \\ Beata Woźniak-Jęchorek ${ }^{4}$
}

\begin{abstract}
The aim of this paper is to fill the cognitive gap regarding the role of sanctions in the protection of a creditor's property rights in the event of an entrepreneur insolvency. The impact of sanctions on transaction costs, including their identification and types, as well as the impact on the protection of creditor rights, has been poorly recognized in the subject literature to date. This article investigates the theory of transaction costs and property rights by providing an identification and description of formal negative sanctions, as well as their impact on counteracting the appropriation of creditors' rights in bankruptcy proceedings. These studies are part of the discussion on the role of formalized negative sanctions, in terms of enforcing behaviours expected by the legislator.
\end{abstract}

Keywords: sanctions, bankruptcy law, transaction costs, property rights theory.

JEL codes: D23, K12, K15, K41.

\section{Introduction}

The structure of bankruptcy regulations in a given country should enable the implementation of desirable goals, i.e. maintaining economic units that have temporary economic problems and reaching a compromise with creditors by means of the debtor's assets as much as possible. While the implementation of these two goals is seemingly connected it is important for bankruptcy to be

\footnotetext{
${ }^{1}$ Article received 22 August 2018, accepted 15 December 2018.

${ }^{2}$ Warsaw School of Economics, Collegium of Business Administration, ul. Madalińskiego 6/8, 02-513 Warszawa, Poland.

${ }^{3}$ Gdańsk University of Technology, Faculty of Management and Economics, ul. Traugutta 79, 80-233 Gdańsk, Poland.

${ }^{4}$ Poznań University of Economics and Business, Department of Macroeconomics and Development Studies, al. Niepodległości 10,61-875 Poznań, Poland, beata.wozniak-jechorek@ ue.poznan.pl
} 
filed as soon as possible, especially by enterprises that do not foresee an improvement in their ability to compete in the market and are liable to bankruptcy. When an entrepreneur delays the submission of an application it has a negative impact on the value of the property and on creditor satisfaction. It is therefore important to create preventive mechanisms aimed at counteracting belated bankruptcy applications and the removal of assets by the debtor (Babiarz-Mikulska, Czapracka, \& Morawska, 2012). One of the elements of this mechanism are sanctions which form the main focus of this article.

The aim of the paper is to fill the cognitive gap on the role of sanctions in the protection of creditors' property rights in the event of an entrepreneur's insolvency. A study was conducted in Polish courts dealing with bankruptcy cases in order to determine the types of formal and negative sanctions, as well as how they are applied to entrepreneurs-debtors in the event of their applying for bankruptcy and whether there is a relationship between the number of sanctions and the number of bankruptcy claims. ${ }^{5}$ It is assumed that sanctions can be perceived as a part of the transaction costs of contract law enforcement associated with the property rights theory.

In the theoretical background New Institutional Economics and two streams of interrelated research literature are referred to-property rights and transaction costs theories. The property rights theory is at the interface of law, economics and organization theory (Williamson, 1996) and defines the nature of sanctioned human behaviour (norms of behaviour) (Furubotn \& Pejovich, 1972). The transaction costs theory explains the choice of organizational form appropriate transactions that have certain transactional characteristics with the appropriate governance mechanisms (Hennart, 1993; Williamson, 1996).

Property rights theory is well suited for explaining institutional change, specifically in a legal system. This theory provides an evolutionary perspective (Anderson \& Hill, 1975; Libecap, 1989; North, 1990) of the processes through which institutional choices are made (creation of law), where the vested economic interests of contracting parties and potential distributional conflicts are taken into account and help in explaining why inefficient property rights' regimes can persist.

In turn transaction costs economics has a wide application in the social sciences, including economics, finance, marketing, organization theory, political science, sociology, strategic management (Carroll, Spiller, \& Teece, 1999) and law. Both theories are often considered together because some of the theoretical underpinnings of transaction cost theory are deeply rooted in property rights theory.

Consequently, the motivation of this paper is to make a contribution to a better understanding of how factors such as sanctions generate a transaction

\footnotetext{
${ }^{5}$ The primary results of research and recommendations regarding the role of sanctions in the protection of creditors' rights have been presented in the book Understanding capitalism. An evolutionary and institutional approach (Ząbkowicz, Miszewski, Chmielnicki, \& Czech, 2018).
} 
cost and as a consequence lead to a change in property rights. Although many researchers have examined transaction costs, systematic analytical links between sanctions in bankruptcy law and transaction costs continue to be rather scarce. By considering the task of decreasing the gap in law and economics research the main thrust of the article is to show that sanctions in bankruptcy law contribute to the effectiveness of bankruptcy in the economy by eliminating insolvent companies at the stage where it is possible to satisfy the creditors in accordance with bankruptcy law. This law, due to its role in removing insolvent entrepreneurs from the economy maintains the interest of researchers. The research covers factors that affect the recovery rate for creditors in bankruptcy proceedings (Smrčka, Arltová \& Schönfeld, 2017; Cepec \& Kovac, 2016; Mucciarelli, 2013). However, there is a lack of research on the role of sanctions in the protection of creditors' rights.

The sanctions understood as a part of transaction costs can be divided into formal and informal and further into positive and negative ones (Chmielnicki \& Paśnik, 2018).

a. Formal negative sanctions characterize the legal system, which in fact monopolized their use in social relations. The reasons behind this are the ease of assessment by the parties involved of the negative consequences of breaching the rules of conduct protected in this way, as well as the psychological value of the simplicity of the retaliation principle, i.e. criminal sanctions.

b. Informal negative sanctions are most often associated with religious, social, ethical or moral norms, although they have the same effect as formal sanctions. They create a specific penalty element which is actually their only similarity. The fact that they are created by individual communities is the reason behind the existence of many catalogues of informal sanctions. The very process of creating rules of conduct-depending on the group's degree of formalization-can be of either a bottom-up character (spontaneous, a significant part of the population takes part in their creation), or top-down (set up, formulated by its leaders). Changes in the level of the formal sanction affect the level of informal sanctions imposed (Daughety \& Reinganum, 2016, p. 359).

c. Positive formal sanctions determine the type and extent of benefits possible to obtain compliance with specific legal norms while they can directly define these benefits (e.g. freeing oneself from personal liability for debts by board members of a limited liability company in the event of filing for bankruptcy within the statutory period-fourteen days-art. 299 of the Civil Code, finder's reward in civil law, a crown witness in criminal law, distinctions in business relations) or indirectly, e.g. faith in civil law, extraordinary mitigation of penalties in criminal law or concession procedures in administrative law.

d. Positive informal sanctions in their essence constitute a desirable gratification for the group as a whole for their members, from the point of view of 
the groups' interests, behaviour. This fact fundamentally determines the basic features of sanctions which include the voluntarily determined duration of a given sanction, its content and dimension as well as the actual premises and informal procedure for granting a stay of execution, the impact of which is limited in time.

Pursuant to the Bankruptcy and Reorganization Law, ${ }^{6}$ hereinafter referred to as "puin", the entrepreneur-the debtor is obliged, not later than fourteen days from the day on which the basis for bankruptcy appeared, to submit an application to the court for a declaration of bankruptcy-art. 21 "puin". If the statutory deadline is exceeded, the subject is liable under: bankruptcy and reorganization law (art. 373 "puin"), criminal law (art. 586 of the Code of Commercial Companies, hereinafter referred to as the ksh), civil law (art. 21 par. 3 "puin", art. 299 of the Code of Commercial Companies) and tax law (art. 116 of the Tax Code, hereinafter referred to as "op" $)^{7}$. It was concluded for the purpose of this article that the court dismissal of an application for the insolvency of an entrepreneur due to lack of assets to cover the costs of bankruptcy proceedings (the "poverty" of the bankrupt estate-art. 13 "puin"), would mean a belated submission made by the management.

The purpose of the bankruptcy and reorganization law enforced by the legislator is to develop a mechanism for filing bankruptcy at an early stage in the course of business for insolvent entrepreneurs so that creditors would receive at least some satisfaction. This is the origin of the time-limit set out by the law: fourteen days from the date on which the basis for filing for bankruptcy appeared when the entrepreneur became insolvent. ${ }^{8} \mathrm{~A}$ court dismissal of filing for bankruptcy due to the lack of assets to cover the costs of bankruptcy is caused by a belated submission, and creditors will not be satisfied in the bankruptcy proceedings. Formal, negative and positive sanctions are to counteract such an occurrence. Only formal, negative sanctions were analyzed in this study. The authors also analyze the sanctions related indirectly to exceeding the deadline for filing for bankruptcy contained in the Penal Code, i.e. art. 300 of the Criminal Code, hereinafter: Penal Code, 301 PC, 302 PC. They penalize behaviour that occurs when the entrepreneur is already in a state of insolvency and the legislator considers them illegal.

The remainder of this paper is as follows. Section 1 discusses the foundations and changes in bankruptcy law. Section 2 focuses on key theoretical contributions of transaction costs and the property rights theory from law and economics. Section 3 presents the data and empirical findings.

\footnotetext{
${ }^{6}$ The Bankruptcy and Reorganization Law of 28 February 2003 (Journal of Laws of 2003, No. 60 , item 535, as amended).

${ }^{7}$ A precise synopsis of sanctions for failing to file for bankruptcy is available from the authors upon request.

${ }^{8}$ From 2016 this period has been extended to 30 days.
} 


\section{Changes in bankruptcy law}

During the last few years Poland has taken legislative action to reform the bankruptcy law three times-in 2003, in the Act of February 28th, 2003, it replaced the existing bankruptcy law and the law on arrangement proceedings of 1934, while the Act of May 15th, 2015 amended the current regulations from January 1st, 2016. The 2003 Act changed the axiological foundations of bankruptcy proceedings which led to the primacy of the principle of creditor protection over the need to protect the debtor and his company. The principle of the primacy of creditors' interests results in further interests such as the interests of the bankrupt (entrepreneur in the rehabilitation process), and the interests of the employees of the bankrupt become secondary. In deciding to replace the bankruptcy law of October 24th, 1934 with the new Bankruptcy and Reorganization Act (Act of 28 February 2003, Journal of Laws No. 60 item 535 , as amended), the Polish legislator redefined the objectives of the regulation. As previously mentioned, the Polish legislator, as the preeminent persona in regulation, aspired towards creditor satisfaction. In the justification of the draft Act of February 28th, 2003 on Bankruptcy and Reorganization Law (Journal of Laws No. 60, item 535, as amended):

It is in the interest of society to not allow such insolvencies. Any insolvency of an entrepreneur should lead to bankruptcy proceedings as soon as possible in order to satisfy creditors with the assets of an insolvent debtor as soon as possible. In analyzing the axiology of the new bankruptcy and rehabilitation law the legislator and commentators have pushed aside other interests, especially the interests of the failed entrepreneur, his employees and, more broadly, the public interest in maintaining jobs and competitive production. Art. 2 of the Act of February 28th, 2003, the Bankruptcy and Reorganization Law provides the definition of this act and indicates the direction of teleological interpretation defining the rules of conduct of the debtor's enterprise. Maintaining a debtor's enterprise should only take place if so doing does not interfere with the interests of the creditors, where reasonable considerations permit. Such formulated goals of bankruptcy proceedings do not allow for balancing the interests of the debtor and creditors from the point of view of shaping economic relationships. The content of art. 2 completely changes the objectives of bankruptcy proceedings in the field of arrangement procedures in relation to the previous legal status. ${ }^{9}$ When reforming the bankruptcy law, the Polish legislator integrated the bankruptcy and arrangement proceedings and chose the possibility of smoothly transitioning from one proceeding to the other, depending on the economic and financial condi-

${ }^{9}$ The Bankruptcy Law Ordinance of the President of the Republic of October 24th, 1934 Bankruptcy Law (unified text, Journal of Laws No. 118 of 1991, item 512, as amended). 
tions of the bankrupt individual, while depriving the debtor of the previously privileged position granted to him in art. 1 of the Law on arrangement proceedings in relation to the creditor's position. Until this time creditors had no right to submit arrangement proposals which was an advantage for the debtor, who fell into debt as a result of exceptional and independent circumstances

and could still have full autonomy in business management decisions. The law passed in 2003 was therefore much more restrictive than the one prevailing before and the opinions of the authors differs from the views of Allerhand (1937) who, commenting on the facts of bankruptcy, stated that "declaring bankruptcy in the event of debt cessation may lead to the destruction of a buyer (...) who is able to obtain the funds needed to pay off any debts from the income of his company, but cannot immediately satisfy his creditors because of exceptional conditions". The Polish legislator identified payment blockades as the main regulatory problem of bankruptcy law but when constructing new legal solutions in terms of their elimination did not take into account that, apart from microeconomic factors, macroeconomic factors also operate in the open market economy. Internal factors such as: the poor quality of business management, low effectiveness of financial control and low quality of working capital management, as well as poorly set cost levels and too widespread scales of operations can and often do lead to the loss of financial liquidity and the inability to settle liabilities. However, external factors such as: the level of intensity of external competition, changes in market demand, changes in prices, services and materials and changes in fiscal and monetary policy of the state and instability of the institutional and legal environment in which the entrepreneur operates, can effectively destroy entire industries and sectors.

On June 9th, 2015 the President of Poland signed the Restructuring Law. This act radically changed the approach to entrepreneurs experiencing financial problems. It introduced four restructuring proceedings, including one sanction, as well as changes to the definition of entrepreneur bankruptcy. The restructuring proceedings include:

1. Arrangement approval procedure.

2. Accelerated and "ordinary" arrangement procedures.

3. Sanitation proceedings.

The purpose of the restructuring proceedings is to avoid the bankruptcy of the debtor by allowing him to restructure by making an arrangement with creditors. In the case of rehabilitation proceedings this also means carrying out rehabilitation activities and securing suitable creditor rights. The new regulation foresees a return to the solutions of the inter-war period (a separate regulation for bankruptcy and restructuring proceedings). However, it did not take into account the basic assumption of regulation of the interwar period-arrangement proceedings were in principle only available to entrepreneurs who fell into financial difficulties due to extraordinary circumstances. 
The basic purposes of the regulation are:

1. Providing entrepreneurs and their contractors with effective instruments for restructuring, while maximizing the protection of creditors' rights.

2. Ensuring institutional autonomy of restructuring proceedings in isolation from stigmatizing bankruptcy proceedings.

3. Introducing the principle of subsidiarity bankruptcy proceedings as an ultima ratio to the economic failure of the restructuring.

4. Increasing the rights of active creditors.

5. Maximizing the speed and efficiency of restructuring and bankruptcy.

6. The formalization of proceedings and a more widespread use of modern ICT tools.

7. The increased liability of unreliable debtors and bankrupt individuals.

The new regulation is part of a new approach to business insolvency in the European Commission Recommendation of March 12th 2014 (European Commission Recommendation, 2014) published on March 14th, 2014 in the Official Journal of the European Union L 74 of March 14th, 2014. The aim of the regulation is to ensure that profitable companies in financial difficulties, irrespective of their place of establishment within the Union, have access to national insolvency frameworks, enabling restructuring at an early stage. The purpose of this is to prevent their insolvency, thus maximizing the total value for creditors, employees, owners and for the entire economy. The aim of the regulation is also to enable honest entrepreneurs who were declared bankrupt by giving them a second chance within the Union.

\section{Law \& economics-property rights and transaction costs theory}

Beginning in the early 1960s Law \& Economics has changed the common understanding of legal rules and institutions and the practice of law. Expanding the economic analysis into the more traditional areas of the law, such as property, contracts, torts, criminal law and procedure and constitutional law, the scientific theory was provided to predict the effects of legal sanctions on behaviour. To economists, sanctions look like prices and presumably, people respond to these sanctions much as they respond to prices. People respond to higher prices by consuming less of the more expensive good; presumably people also respond to more severe legal sanctions by doing less of the sanctioned activity (Cootler \& Ulen, 2016). Moreover, sanctions not only have the instrumental function of deterring people from undesired behaviour, but they also have the ability to convey moral norms. As such, they may create a moral motivation not to engage in the sanctioned behaviour (Mulder, 2018, p. 331).

The economic analysis of the law began with the publication The problem of social costs by R. H. Coase (1960) and his famous Coase Theorem which notes: "in the absence of transaction costs, the allocation of resources is independent 
of the distribution of property rights" (1960). This means that the distribution of property rights can be crucial to the efficient use of resources when transaction costs are not zero.

From a legal viewpoint property is a bundle of rights. These rights describe what people may and may not do with the resources they own: the extent to which they may possess, use, develop, improve, transform, consume, deplete, destroy, sell, donate, bequeath, transfer, mortgage, lease, loan, or exclude others from their property. Property rights can be defined here as the nature of sanctioned human behaviour (norms of behavior) (Furubotn and Pejovich, 1972). Such sanctioned behaviours allow people the right to use resources within the 'class of non-prohibited uses' (Alchian, 1965). Property rights are " $[t]$ he rights of individuals to the use of resources... supported by the force of etiquette, social custom, ostracism and formal legally enacted laws supported by the states' power of violence or punishment" (Alchian, 1965, p. 129).

From the economic perspective an analysis is made of how alternative bundles of rights create incentives to use resources efficiently. An efficient use of resources maximizes the wealth of a nation. Differences in efficiency must depend on transaction costs, which are the costs of exchange. In this context the institutions are very important as a medium for reducing transaction costs and obtaining a greater efficiency in economic performance (North, 1992).

Referring to the differences between transaction costs and property rights theories, one characteristic is important to this research. Property rights theory views the sources of imperfections in the market as unclearly defined and/or insecure property rights (see Table 1). Unclearly defined property rights are the

Table 1. General distinction among property rights and transaction costs theory

\begin{tabular}{|l|c|c|}
\hline \multicolumn{1}{|c|}{ Contents } & Property rights theory & Transaction costs theory \\
\hline Unit of analysis & Institution & Transaction \\
\hline Focal dimension & Property rights & Various types of asset specificity \\
\hline Focal cost concern & $\begin{array}{c}\text { Externalities } \\
\text { Rent-seeking }\end{array}$ & $\begin{array}{c}\text { Maladaptation } \\
\text { Holdup problems }\end{array}$ \\
\hline Contractual focus & $\begin{array}{c}\text { Ex ante property rights alloca- } \\
\text { tion and expost distributional } \\
\text { conflicts }\end{array}$ & $\begin{array}{c}\text { Choice of (expost) governance } \\
\text { mechanism }\end{array}$ \\
\hline Theoretical orientation & Comparative assessment & Comparative assessment \\
\hline Strategic intent & Stakeholder view & $\begin{array}{c}\text { Shareholder view } \\
\text { Sources of market } \\
\text { frictions }\end{array}$ \\
\hline
\end{tabular}

Source: (Kim \& Mahoney, 2005, p. 231). 
rights that have not been assigned to the contractual party with the economic incentive and ability to maximize utilization of the resource, while insecure property rights are the rights that can be appropriated by others. Transaction cost theory adds a few more conceptual transaction characteristics, namely asset specificity and opportunism (see Table 1). Both theories note that there are some incentives or motives that can support unwanted behaviour also within the legal system.

One of the fundamental questions of property law is what are the remedies for the violation of property rights? This question concerns how a court should respond when a private person or the government interferes with someone's property rights. To answer this question the differences in efficiency of remedies (sanctions) which must depend on transaction costs are evaluated.

\section{Judicial practice of sanctions in Poland}

\subsection{Data and methodology}

As part of the study of judicial practice in the area of application of sanctions the data was obtained from courts in the three largest districts in Poland (Wrocław-S1, Warsaw-S2 and Gdańsk-S3). The data for S1 and S2 districts was from 2004-2014 and for the S3 district was from 2005-2014. The method chosen for the study allowed an analysis of court practice in real conditions, including the number of applications for bankruptcy being dismissed due to the "poverty" of the bankruptcy estate and the sanctions applied by courts of art. 299 of the Commercial Companies Code, 586 of the Code of Commercial Companies, 300 Criminal Code, hereinafter referred to as the Penal Code, 301 Penal Code, 302 Penal Code and 373 Bankruptcy Law. Acquiring research material was particularly difficult because the courts do not keep any statistics on the sanctions applied in case of dismissal of the application for bankruptcy because of the "poverty" of the bankruptcy estate.

In the following stage the non-parametric tau Kendall test was used to study the correlation between the number of rejected applications and the sanctions from art. 300 of Criminal Code and art. 373 Bankruptcy Law. In the remaining cases the study of dependence was found to be warrantless due to the small number of observations and incomplete data.

Finally, the number of imposed bans in art. 373 of Bankruptcy Law to the number of dismissed petitions for declaration of bankruptcy pursuant to art. 13 of Bankruptcy Law was examined. A large percentage of applications filed by entrepreneurs in Poland for the declaration of bankruptcy is dismissed because of the "poverty" of the bankruptcy estate which means that they are submitted by entrepreneurs too late. Figure 1 presents the number of bankruptcy submissions made in bankruptcy courts and the substantive method of handling them. 


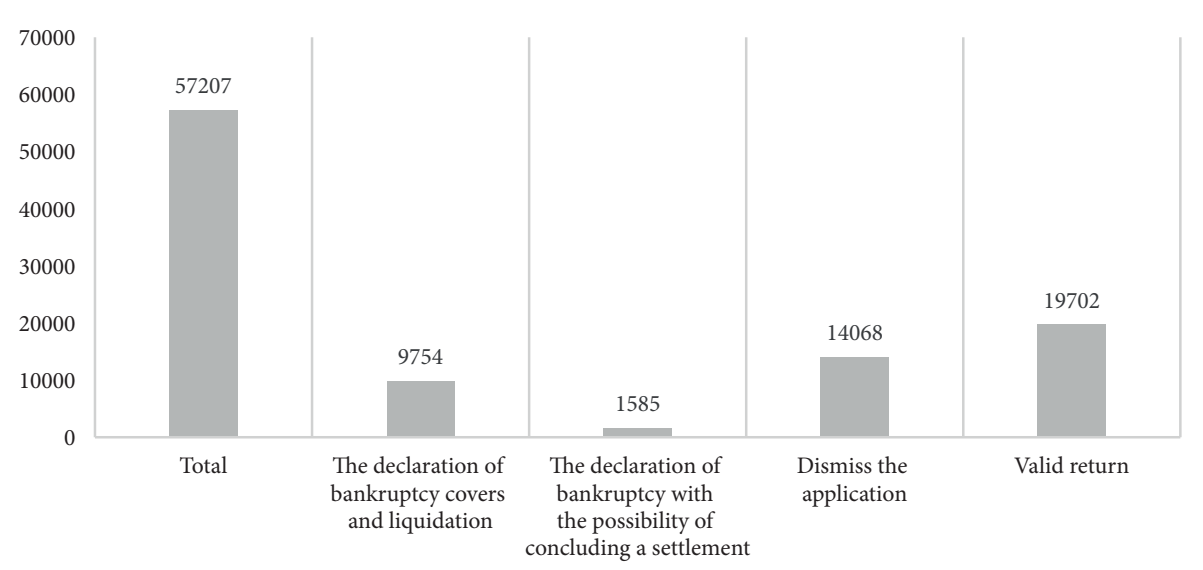

Figure 1. Bankruptcy cases in district courts in 2004-2015

Source: Based on statistical data from the Ministry of Justice.

Dismissing applications is a method that is used in one third of the cases in the bankruptcy court. However, it should be noted that the Ministry of Justice has only been recording how many out of all dismissed petitions for bankruptcy are rejected due to poverty of bankruptcy estate since 2013. The available data indicates that the amount of dismissed bankruptcy claims due to the poverty of the bankruptcy estate in Poland, collated with the total declarations of bankruptcy in the group of entrepreneurs in 2013-2015, was equal to $24.4 \%$; $24.32 \% ; 26,04 \%$ (Bankruptcy, restructuring, b.d.). This is a large percentage which shows the low effectiveness of the bankruptcy system.

\subsection{Dismissed applications for bankruptcy and sanctions: empirical researches}

As has been presented entrepreneurs who file for bankruptcy too late should be more negatively judged as they force the court to dismiss the bankruptcy submission in accordance with art. 13 Bankruptcy Law. Therefore, it is necessary to consider what determinants could have an impact on the fact that entrepreneurs will apply earlier for bankruptcy, and what the creditors would be able to recover. One of the deterrents (preventive) factors against belated filing for bankruptcy are the legislator's sanctions. In order to determine this the types and intensity of the court use of sanctions in such cases were checked. It should be emphasized that the data was not always complete which resulted from the lack of obligation for courts to register such information (see Table 2).

Based on the data presented in Table 2 it should be noted that:

1. The court was able to state the number of dismissed applications for bankruptcy under art. 13 of Bankruptcy Law only for the region of Gdańsk. In the remaining instances the courts only had information on the total number of dismissed applications for bankruptcy, regardless of the cause. 


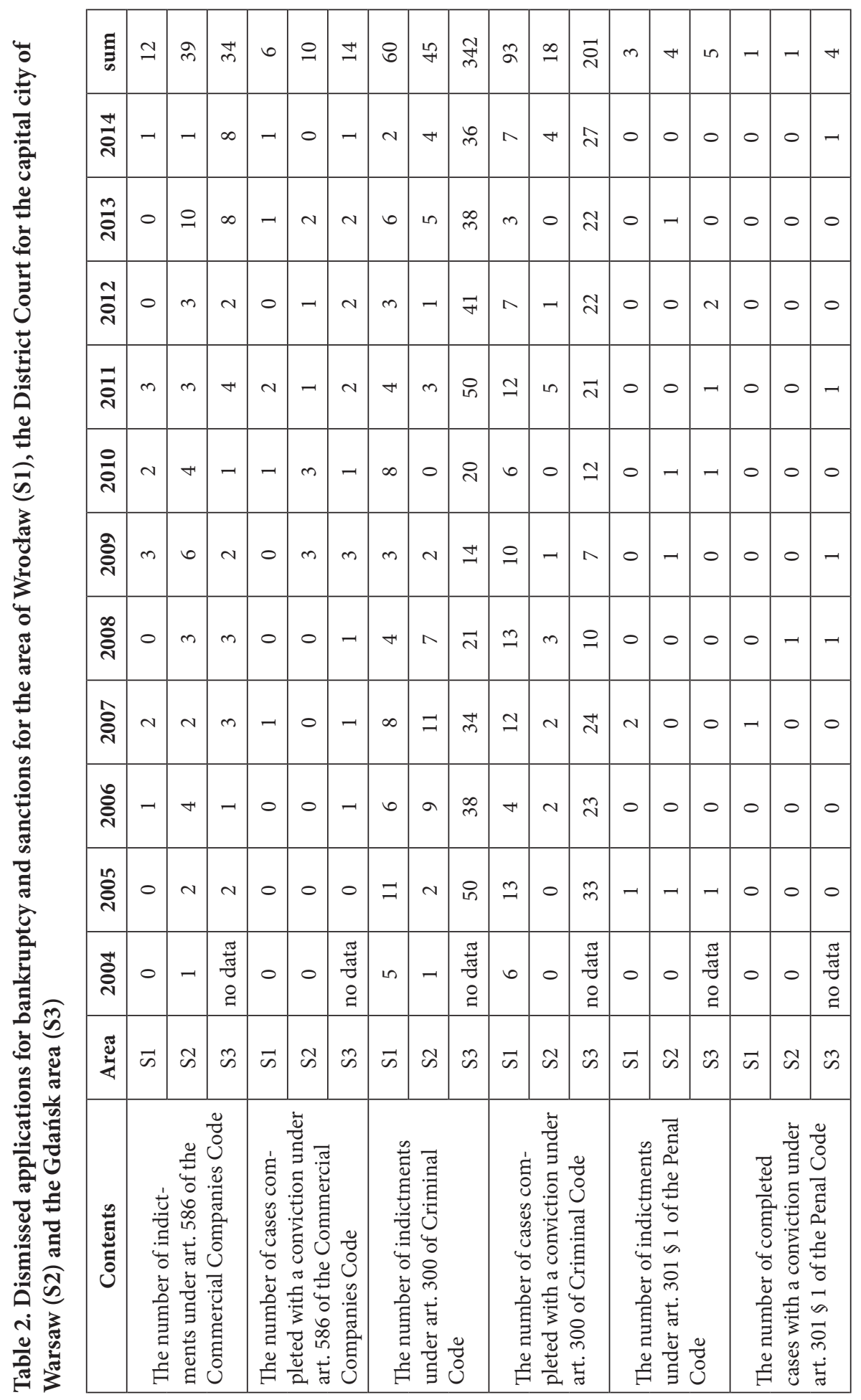




\begin{tabular}{|c|c|c|c|c|c|c|c|c|c|c|c|c|c|c|c|c|c|}
\hline 0 & $\sim$ & $H$ & $\neg$ & 0 & 0 & - & N & 0 & 0 & 0 & 0 & $\sim$ & $\rightarrow$ & & $\sim$ & - & $m$ \\
\hline 0 & 0 & 0 & 0 & 0 & 0 & 0 & 0 & 0 & 0 & 0 & 0 & 0 & 0 & $N$ & 0 & 0 & 0 \\
\hline 0 & 0 & 0 & 0 & 0 & 0 & 0 & - & 0 & 0 & 0 & 0 & 0 & 0 & $N$ & 0 & 0 & 0 \\
\hline 0 & 0 & - & 0 & 0 & 0 & 0 & 0 & 0 & 0 & 0 & 0 & 0 & 0 & $N$ & 0 & 0 & - \\
\hline 0 & 0 & 0 & 0 & 0 & 0 & 0 & 0 & 0 & 0 & 0 & 0 & $\sim$ & 0 & $n$ & $\sim$ & 0 & - \\
\hline 0 & 0 & 0 & $\neg$ & 0 & 0 & - & 0 & 0 & 0 & 0 & 0 & 0 & 0 & $\neg$ & 0 & 0 & - \\
\hline 0 & $\sim$ & $m$ & 0 & 0 & 0 & 0 & $\neg$ & 0 & 0 & 0 & 0 & 0 & - & 0 & 0 & - & 0 \\
\hline 0 & 0 & 0 & 0 & 0 & 0 & 0 & 0 & 0 & 0 & 0 & 0 & 0 & 0 & 0 & 0 & 0 & 0 \\
\hline 0 & 0 & 0 & 0 & 0 & 0 & 0 & 0 & 0 & 0 & 0 & 0 & 0 & 0 & 0 & 0 & 0 & 0 \\
\hline 0 & 0 & 0 & 0 & 0 & 0 & 0 & 0 & 0 & 0 & 0 & 0 & 0 & 0 & 0 & 0 & 0 & 0 \\
\hline 0 & 0 & 0 & 0 & 0 & 0 & 0 & 0 & 0 & 0 & 0 & 0 & 0 & 0 & 0 & 0 & 0 & 0 \\
\hline 0 & 0 & 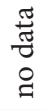 & 0 & 0 & 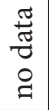 & 0 & 0 & 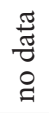 & 0 & 0 & 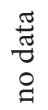 & 0 & 0 & 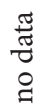 & 0 & 0 & 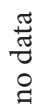 \\
\hline$\vec{n}$ & సี & $\ddot{n}$ & $\vec{n}$ & $\tilde{\omega}$ & $\tilde{n}$ & $\vec{n}$ & ๙ู & $\tilde{n}$ & $\vec{\omega}$ & బี & $\tilde{n}$ & $\vec{n}$ & กี & $\tilde{n}$ & $\vec{\omega}$ & $\tilde{\infty}$ & $\tilde{n}$ \\
\hline \multicolumn{3}{|c|}{ 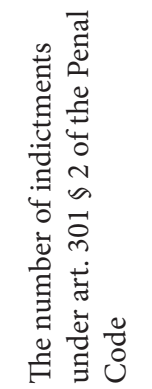 } & \multicolumn{3}{|c|}{ 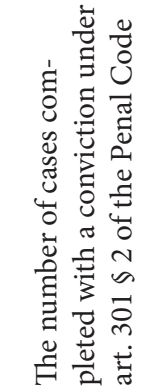 } & \multicolumn{3}{|c|}{ 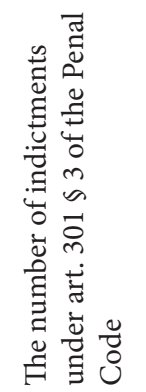 } & \multicolumn{3}{|c|}{ 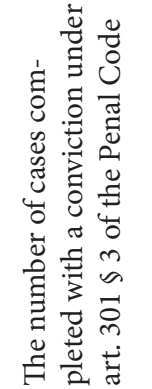 } & \multicolumn{3}{|c|}{ 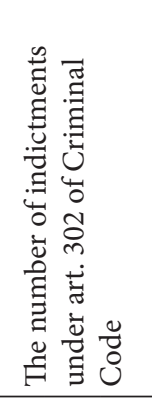 } & \multicolumn{3}{|c|}{ 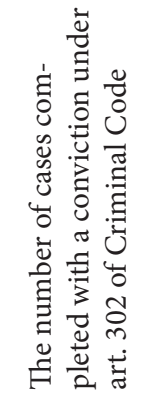 } \\
\hline
\end{tabular}




\begin{tabular}{|c|c|c|c|c|c|c|c|c|}
\hline$\vec{m}$ & $\vec{\nabla}$ & $\vec{b}$ & 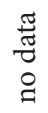 & $\stackrel{\Xi}{\Xi}$ & $\stackrel{+}{\infty}$ & $\stackrel{+}{N}$ & $\begin{array}{l}\vec{\alpha} \\
\underset{+}{+}\end{array}$ & 。ㅇ \\
\hline$\vec{n}$ & $\stackrel{ల}{~}$ & $\simeq$ & 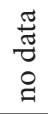 & 户 & $a$ & $\stackrel{\infty}{0}$ & $\overrightarrow{0}$ & రె \\
\hline$\stackrel{\sim}{\sim}$ & $\stackrel{2}{\sim}$ & ले & 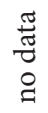 & 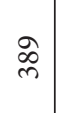 & $\Re$ & $\stackrel{R}{R}$ & $\underset{\perp}{\beth}$ & 12 \\
\hline$\stackrel{2}{\sim}$ & $\approx$ & $\stackrel{H}{\sim}$ & 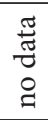 & Oे & $2 n$ & กิ & $\begin{array}{l}\overrightarrow{0} \\
\stackrel{n}{n}\end{array}$ & $\stackrel{N}{N}$ \\
\hline Fे & $\stackrel{\llcorner}{\sim}$ & 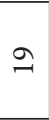 & 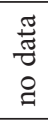 & ลૂ & $\ddot{\sim}$ & fo & $\stackrel{\vec{\beth}}{\beth}$ & $\hat{6}$ \\
\hline$\stackrel{\leftrightarrow}{\sim}$ & 10 & $\simeq$ & 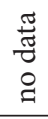 & 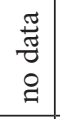 & \begin{tabular}{|l|}
\multirow{J}{J}{} \\
J \\
ఏ \\
\end{tabular} & ช్ & $\underset{\infty}{\infty}$ & $\infty$ \\
\hline$\stackrel{0}{-}$ & $\exists$ & in & 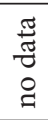 & 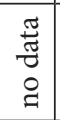 & \begin{tabular}{|l|}
\multirow{J}{*}{} \\
J \\
$\varrho$ \\
$\varrho$
\end{tabular} & $\hat{n}$ & $\vec{\Xi}$ & )ิ \\
\hline$\stackrel{20}{n}$ & $\simeq$ & $a$ & 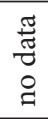 & 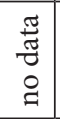 & 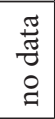 & $\hat{\curvearrowright}$ & $\overrightarrow{8}$ & r \\
\hline$\stackrel{\sim}{\sim}$ & $\Xi$ & $\Xi$ & 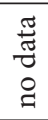 & 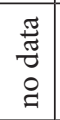 & 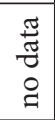 & 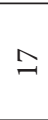 & $\vec{n}$ & $\stackrel{m}{m}$ \\
\hline बे & $\stackrel{\sim}{\sim}$ & $\stackrel{\infty}{-1}$ & 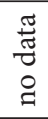 & 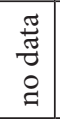 & 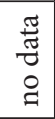 & ల & $\vec{\infty}$ & กิ \\
\hline F & $\stackrel{n}{n}$ & $a$ & \begin{tabular}{l}
\multirow{J}{J}{} \\
J \\
○
\end{tabular} & 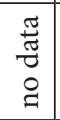 & 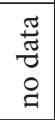 & Hn & $\overrightarrow{\widetilde{0}}$ & $\stackrel{N}{N}$ \\
\hline 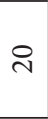 & $\infty$ & 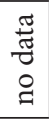 & 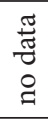 & 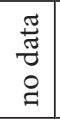 & 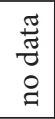 & ţ & స్రి & 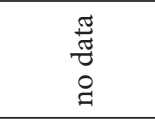 \\
\hline$\vec{n}$ & $\tilde{\omega}$ & $\tilde{n}$ & $\bar{n}$ & $\tilde{\omega}$ & $\tilde{s}$ & $\bar{\omega}$ & ஸै & $\tilde{n}$ \\
\hline \multicolumn{3}{|c|}{ 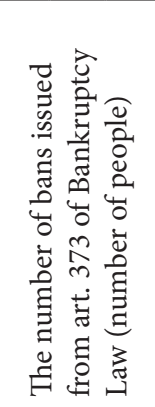 } & \multicolumn{3}{|c|}{ 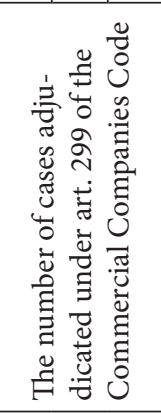 } & \multicolumn{2}{|c|}{ 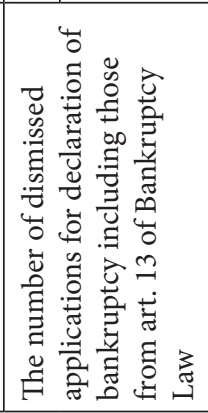 } & 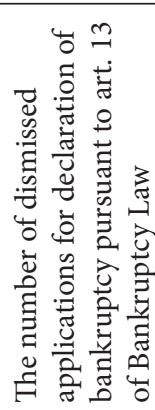 \\
\hline
\end{tabular}


2. Sanctions are most often applied: from art. 300 of Criminal Code and art. 373 of Bankruptcy Law. The data for sanctions under art. 299 of the Code of Commercial Companies is incomplete.

In the following stage the non-parametric tau Kendall test was used to study the correlation between the number of rejected applications and the sanctions from art. 300 of Criminal Code and art. 373 of Bankruptcy Law. In the remaining cases the study of dependence was found to be warrantless due to the insignificant number of observations and incomplete data. The total number of dismissed applications for bankruptcy was taken into account in the case of Wrocław and Warsaw whereas the number of dismissed petitions for bankruptcy in Gdańsk was based on art. 13 of Bankruptcy Law. The analysis was carried out with two variants, i.e. without a time shift and with a time shift of one year of sanctions in relation to remote applications. This approach results from the fact that proceedings involving the imposition of sanctions take a lot of time and it is unlikely for a sentence to be passed in the same year as the dismissal of a bankruptcy application. The significance level has been constituted as $\alpha=0.05$. The results are presented in Table 3 .

Table 3. The results of a correlation analysis between dismissed applications and selected sanctions (without a time shift and with a time shift)

\begin{tabular}{|c|c|c|c|}
\hline Contents & $\begin{array}{c}\text { The number of bans } \\
\text { issued from art. } 373 \\
\text { of Bankruptcy Law }\end{array}$ & $\begin{array}{c}\text { The number of } \\
\text { indictments under } \\
\text { art. } 300 \text { of Criminal } \\
\text { Code }\end{array}$ & $\begin{array}{l}\text { The number of } \\
\text { cases completed } \\
\text { with a conviction } \\
\text { under art. } 300 \text { of } \\
\text { Criminal Code }\end{array}$ \\
\hline \multicolumn{4}{|c|}{ Region - Wrocław - S1 } \\
\hline $\begin{array}{l}\text { The number of dis- } \\
\text { missed applications for } \\
\text { bankruptcy }\end{array}$ & $\begin{array}{c}\text { tau Kendall }=0.257 \\
(0.944) \\
p \text {-value }=0.271 \\
(0,000) \\
N=11(10)\end{array}$ & $\begin{array}{c}\text { tau } \text { Kendall }=-0.094 \\
(-0.023) \\
p \text {-value }=0.686 \\
(0.925) \\
N=11(10)\end{array}$ & $\begin{array}{c}\text { tau Kendall }=-0.396 \\
(-0.138) \\
p \text {-value }=0.089 \\
(0.578) \\
N=11(10)\end{array}$ \\
\hline \multicolumn{4}{|c|}{ Region - the capital city of Warsaw - S2 } \\
\hline $\begin{array}{l}\text { The number of dis- } \\
\text { missed applications for } \\
\text { bankruptcy }\end{array}$ & $\begin{array}{c}\text { tau Kendall }=-0.037 \\
(0.854) \\
p \text {-value }=0.875 \\
(0,000) \\
N=11(10)\end{array}$ & $\begin{array}{c}\text { tau Kendall }=-0.426 \\
(-0.135) \\
p \text {-value }=0.068 \\
(0.587) \\
N=11(10)\end{array}$ & $\begin{array}{c}\text { tau Kendall }=-0.452 \\
(-0.047) \\
p \text {-value }=0.053 \\
(0.849) \\
N=11(10)\end{array}$ \\
\hline \multicolumn{4}{|c|}{ Region - Gdańsk - S3 } \\
\hline $\begin{array}{l}\text { The number of dis- } \\
\text { missed applications for } \\
\text { declaration of bank- } \\
\text { ruptcy pursuant to art. } \\
13 \text { of Bankruptcy Law }\end{array}$ & $\begin{array}{c}\text { tau Kendall }=0.000 \\
(0.571) \\
p \text {-value }=1.000 \\
(0.032) \\
N=10(9)\end{array}$ & $\begin{array}{c}\text { tau Kendall }=0.184 \\
(0.6) \\
p \text {-value }=0.459 \\
(0.024) \\
N=10(9)\end{array}$ & $\begin{array}{c}\text { tau Kendall }=-0.159 \\
(0.114) \\
p \text {-value }=0.522 \\
(0.668) \\
N=10(9)\end{array}$ \\
\hline
\end{tabular}

Note: The results with a time shift are given in brackets. 
According to these results (Table 3 ) it can be concluded that there is a statistically significant relationship between the number of dismissed applications for bankruptcy and the number of bans in the next year from art. 373 of Bankruptcy Law in each region. Apart from one exception no relationship was found between the number of dismissed applications and sanctions under art. 300 of the Penal Code (the exception is the area of Gdańsk and the relationship between the number of dismissed applications and the number of indictments submitted in the following year from art. 300 of the Penal Code).

Finally, a study was made of the number of imposed bans in art. 373 of Bankruptcy Law to the number of dismissed petitions for declaration of bankruptcy pursuant to art. 13 of Bankruptcy Law. The analysis was conducted only for the Gdańsk region, as this area was the only one with available data (see Figure 2).

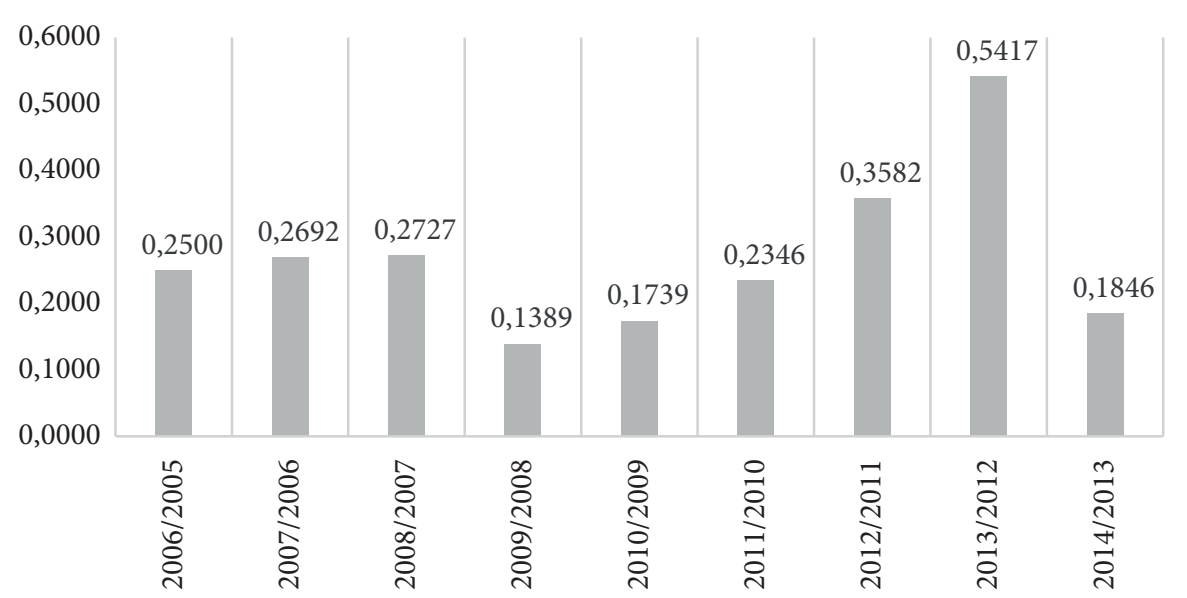

Figure 2. Relationship between the number of bans issued under art. 373 of Bankruptcy Law and the total number of dismissed applications filed in the previous year for declaration of bankruptcy pursuant to art. 13 of Bankruptcy Law (area-Gdańsk-S3)

Figure 2 shows that these shares are diversified in individual periods with only one exceptionally being equal to more than $50 \%$. This means that a relatively small proportion of insolvent debtors who have filed for bankruptcy too late are punished with a ban on doing business. Many of them do not suffer the consequences.

\subsection{Findings}

The results of the empirical research show that Polish entrepreneurs postpone applying for bankruptcy hoping to overcome financial difficulties. In the case of limited liability companies, which separate ownership from management 
functions obliging board members to submit a declaration of bankruptcy may contradict the objectives set by the owners, i.e. maintaining the enterprise and jobs thereof. They do not submit such applications thus risking their personal responsibility (often unknowingly). Sometimes it is also the case that entrepreneurs are not even aware of the obligation to submit an application for bankruptcy in such a short time, or about its meaning.

The aim of the study conducted in this section was to analyze the functioning sanctions. Data analysis concludes that:

1. The court was only able to state the number of dismissed petitions for declaration of bankruptcy pursuant to art. 13 of Bankruptcy Law. in District S3. In the other districts courts only had information on the total number of dismissed applications for bankruptcy irrespective of the reason.

2. Sanctions are most often applied: from art. 300 of Criminal Code and art. 373 of Bankruptcy Law. The data regarding art. 299 of the Code of Commercial Companies is incomplete.

3. There is a correlation between the number of dismissed applications for bankruptcy and the number of bans in the year succeeding (art. 373 of Bankruptcy Law).

4. Courts applied sanctions under art. 373 of Bankruptcy Law only to the insolvent entrepreneurs that had a record of the bankruptcy estate. (Depending on the year, the share of the number of bans issued under art. 373 of Bankruptcy Law in the total number of dismissed applications filed in the previous year for bankruptcy under art. 13 of Bankruptcy Law in the area of Gdansk ranged from $13.89 \%$ to $54.17 \%$ ). Based on the data it can also be presumed that other sanctions are applied relatively rarely.

The results of the research initially indicate the following practice undertaken by both creditors and debtors. In the event of the dismissal of a bankruptcy application due to the poverty of the bankruptcy estate creditors demand a ruling in the bankruptcy court against the persons prohibiting the running of a business. These people delay the filing of an application for bankruptcy discouraged by the possibility of satisfying the creditors. It should be added that the prohibition decision depends on their activity as the court does not act ex officio in this respect. However, in the event of threatening insolvency or bankruptcy, debtors thwart and deplete the satisfaction of their creditor by removing, hiding, disposing of, donating, destroying and physically or otherwise encumbering property by a mortgage or damaging it. It should also be noted that sanctions are applied by the courts relatively rarely, which negatively affects the implementation of the preventive function. As a result, many insolvent entrepreneurs prefer to take the risk of not filing for bankruptcy within the statutory period while others may do this unknowingly (as a result of ignorance of the law). 


\section{Conclusions}

An efficiently functioning bankruptcy regulation system should ensure maximum reduction of the duration of bankruptcy proceedings and the quickest possible recovery by the creditors of their claims from the assets of the insolvent entrepreneur. Failure to meet this condition has a negative impact on the functioning of the economic system without eliminating from the market economy entities disrupting its proper functioning and delaying the satisfaction of creditors by insolvent debtors. Bankruptcy law which operates at the junction of economics, social policy and criminal law, should be an expression of the values adhered to by society. Sanctions adapted to the chosen bankruptcy model should be possible to enforce.

The differences in bankruptcy regulations are far-reaching across the European Union (EU), even though the principle of universality is contained within the Regulation of the European Parliament and of the Council (EU) No. 2015/848 of May 20th 2015 on bankruptcy proceedings (Journal of Laws UE L 141 of 05/06/2015) along with the decision to initiate proceedings for bankruptcy in any other Member State without the need to comply with any formalities, or the effects that result from the law of the State where proceedings are started. These differences result from different legal traditions and different approaches to business failure.

In Common Law the failure to run a business successfully and the related loss of financial liquidity is treated as an inherent risk of all activities. Legal systems regulate bankruptcy not only in terms of creditor interest but also in terms of the interests of insolvent entrepreneur. The interest of an insolvent entrepreneur comes down to a quick and lawful cessation of economic activity, which has ceased to be profitable. It allows the possibility to close the activity and start a new business. The interest of an insolvent entrepreneur is also the restructuring of the company and the possibility of continuing in business. In turn the interest of creditors is to recover as many claims as possible from the insolvent entrepreneur. That is why the creditors are more interested in the quick liquidation of an insolvent entrepreneur. Due to the lack of economic competence of judges dealing with bankruptcy and restructuring advisors the creditor may be reluctant to request a restructuring through the courts.

Under the influence of Anglo-Saxon solutions, especially Chapter 11 of US bankruptcy law and systematic studies of the effectiveness of bankruptcy institutions in the EU Member States, the European Commission in the Communication from the Commission to the Council, the European Parliament, the European Economic and Social Committee and the Committee of the Regions COM (2007) 584 final-recommend that the focus should not be on bankruptcy law but on the liquidation of endangered enterprises and primarily-on restructuring. Similarly, the European Commission Recommendation (2014) stressed that viable enterprises with financial difficulties, irrespective 
of their place of establishment within the Union, should have access to national insolvency frameworks, enabling restructuring at an early stage. This was to prevent their insolvency, ensuring the maximization of the total value of creditors, employees, owners and the economy as a whole. The aim of the recommendation was also to allow honest entrepreneurs who were declared bankrupt to get a second chance within the Union. Balancing the conflicting interests of creditors and their debtors by reforming the bankruptcy law is, therefore, a valid issue.

Currently, however, there are still major differences in the axiology of bankruptcy law in Europe. Legal systems operating in the EU have so far been aimed at liquidating the bankruptcy estate and safeguarding creditors as well as at maintaining the bankrupt enterprise and jobs. Traditionally the purpose of bankruptcy proceedings was to obtain maximum proceeds from the liquidation of the debtor's assets and to divide them proportionally among creditors. The bankruptcy law from 2003 was primarily intended to protect the interests of other entrepreneur-creditors, who, by creating the possibility of deferred payment, had the right to expect that they would be able to recover at least a part of their receivables if they were unable to pay their debts. The initial role of insolvency was to help the lenders in collecting money from the debtor where the usual mechanisms securing this had failed, and its function was to enforce, punish and deter (Prusak, 2011). Insolvency was perceived as a pathology, an instrument to eliminate inefficient entrepreneurs from the market, a synonym for bankruptcy.

During the study in Poland the bankruptcy and reorganization law was in force under the pro-creditor's model. In business practice entrepreneurs filed applications for bankruptcy too late when the debtor's assets were not even sufficient to cover the costs of the proceedings. This is evidenced by the large number of dismissed applications for bankruptcy.

The results of the study indicate that the bankruptcy law provides a number of sanctions for applying for bankruptcy after the deadline. These constitute an important component of transaction costs in pursuing contract rights in the event of an entrepreneur's insolvency-the debtor. In practice, however, sanctions do not counteract the seizure by creditors of an insolvent entrepreneur's assets-the debtor-and they are not enforced. This means that creditors do not recover their receivables because the bankruptcy court is forced to dismiss the bankruptcy petition. The sanction system is ineffective. Its effectiveness is solely dependent on adherence to bankruptcy law by the participants in the economy. A significant problem in establishing law in Poland is shortterm vision and a lack of a targeted, preempted perspective of the legal protection model that is well-defined and cohesive for the interest groups of the purpose of the regulation. The lack of effectiveness of the proposed solutions causes frequent amendment to bankruptcy law with no concern for the possibility of its implementation in the court practice. 
There is a lack of research on the effectiveness of sanctions intended to ensure the implementation of regulatory objectives set by the legislator. The lawmaking process should be based on an objective assessment of the effects of any regulation. There are still no independent control centers for think-bank bankruptcy institutions in the area examined that could monitor the process of implementing the right to court practice or research into its effectiveness and efficiency. The bankruptcy system does not contribute to the development of entrepreneurship as it should, and economic and financial environments maintain that the legal framework created by bankruptcy law has many weaknesses. In reality dysfunctional regulations and the length of proceedings do not effectively contribute to the return of value to creditors from the perspective of costs and time. The lack of a broader view of this issue is caused by national legislators leading to the repetition of errors before reforms in other countries (e.g. a too restrictive approach to bankruptcy, excessive criminalization, excessive formalism, a lack of predictability of proceedings).

According to the World Bank there is no single, generally applicable reform matrix. Only a regulation that can be fully implemented in economic and judicial practice can be an effective measure to improve the efficiency of bankruptcy proceedings. The proceedings aimed at debt restructuring bring good results only in countries that have adequate infrastructure-experienced judges and lawyers, as well as a fully developed market, in which the assets of the reorganized enterprise can be quickly liquidated. From an economic point of view the World Bank found that the highest recovery rate in countries that are well-off is guaranteed by a moderate simplification of liquidation processes and in countries that are poor-effective debt recovery. Therefore, judicial practice is the key to assessing the effectiveness of the model adopted for bankruptcy proceedings (World Bank, 2015). The research carried out for the purposes of this article will fulfill these recommendations.

\section{References}

Alchian, A. A. (1965). Some economics of property rights. Il Politico, 30, 816-829 (reprinted in Alchian A. A. (Ed.) (1997). Economic Forces at Work (pp. 127-149). Indianapolis: Liberty Fund).

Allerhand, M. (1937). Prawo upadłościowe. Prawo o postępowaniu układowem. Warszawa: Księgarnia F. Hoesicka.

Anderson, T. L., \& Hill P. J. (1975). The evolution of property rights: A study of the American West. Journal of Law and Economics, 18, 163-179.

Babiarz-Mikulska, K., Czapracka, A., \& Morawska, S. (2012). Ocena efektywności procedur upadłościowych wobec przedsiębiorców. Aspekty prawne, ekonomiczne i organizacyjne. Warszawa: Difin.

Bankruptcy, restructuring and restructuring proceedings. Retrieved September 6, 2017 from https://isws.ms.gov.pl/pl/baza-statystyczna/opracowania-wieloletnie/ 
Carroll, G. R., Spiller, P. T., \& Teece, D. J. (1999). Transaction cost economics: Its influence on organizational theory, strategic management, and political economy. In G. R. Carroll, D. J. Teece (Eds.), Firms, markets, and hierarchies: The transaction cost economics perspective (pp. 60-88). New York: Oxford University Press.

Cepec, J., \& Kovac, M. (2016). Carrots and sticks as incentive mechanisms for the optimal initiation of insolvency. DANUBE: Law and Economics Review, 7(2), 79-103.

Chmielnicki, P., \& Paśnik, J. (2018). Rozpoznanie treści instytucji jako warunek sine qua non oceny ich skutków. In A. Ząbkowicz, M. Miszewski, P. Chmielnicki, S. Czech (Eds.), Zrozumieć kapitalizm. Podejście ewolucyjno-instytucjonalne. SosnowiecKraków: FMI, Humanitas Publishing House.

Coase, R. H. (1960). The problem of social cost. Journal of Law and Economics, 3(1), pp. 1-44.

Cootler, R., \& Ulen, T. (2016). Law and Economics (6th ed.). Berkeley: Berkeley Law Books.

Daughety, A. F., \& Reinganum, J. F. (2016). Informal sanctions on prosecutors and defendants and the disposition of criminal cases. Journal of Law, Economics, and Organization, 32(2), 359-394. Retrieved from https://doi.org/10.1093/jleo/ewv020.

European Commission Recommendation of 12 March 2014 on a new approach to business failure and insolvency (2014/135/EU). (2014, March 14). OJ L74, 65-70.

Furubotn, E. G., \& Pejovich, S. (1972). Property rights and economic theory: A survey of recent literature, Journal of Economic Literature, 10, 1137-1162.

Hennart, J. (1993). Explaining the 'swollen middle': Why most transactions are a mix of market and hierarchy. Organization Science, 4, 529-547.

Kim, J., \& Mahoney, J. T. (2005). Property rights theory, transaction costs theory, and agency theory: An organizational economics approach to strategic management. Managerial and Decision Economics, 26, 223-242. http://dx.doi.org/10.1002/ mde. 1218

Libecap, G. D. (1989). Contracting for property rights. New York: Cambridge University Press.

Muciarrelli, F. M. (2013). Not just efficiency: Insolvency law in the EU and its political dimension. European Business Organization Law Review, 14(2), 175+200.

Mulder, L. B. (2018). When sanctions convey moral norms. European Journal of Law and Economics, 46(3), 331-342.

North, D. C. (1990). Institutions, institutional change and economic performance. Cambridge: Cambridge University Press.

North, D. C. (1992). Transaction costs, institutions and economic performance. San Francisco, CA: International Center for Economic Growth Publication.

Prusak, B. (2011). Ekonomiczna analiza upadłości przedsiębiorstw. Ujęcie międzynarodowe Warszawa: CeDeWu.

Smrčka, L., Arltová, M., \& Schönfeld, J. (2017). Quality of insolvency proceedings in selected countries-analysis focused on recovery rates, costs and duration. Administratie si Management Public, (28), 116-132.

The World Bank. (2015). The World Bank principles for effective insolvency and creditor/debtor regimes. http://www.worldbank.org/en/topic/financialsector/brief/theworld-bank-principles-for-effective-insolvency-and-creditor-rights 
Williamson, O. E. (1996). The Mechanisms of Governance, Oxford University Press: New York.

Ząbkowicz, A., Miszewski, M., Chmielnicki, P., \& Czech, S. (Eds.). (2018). Zrozumieć kapitalizm. Podejście ewolucyjno-instytucjonalne Sosnowiec-Kraków: FMI, Humanitas Publishing House. 